\title{
Podwójne wykorzenienie: Losy Japończyków w Kanadzie w czasie drugiej wojny światowej
}

Druga wojna światowa stanowi w dziejach japońskiej społeczności w Kanadzie i USA okres przełomowy i bolesny. Warto zaznaczyć, że jej członkowie już przed wojną doświadczali w obu tych krajach silnej dyskryminacji. Japoński atak na Pearl Harbor przyczynił się do nasilenia wrogości wobec osób pochodzenia japońskiego. Zadawnione uprzedzenia rasowe nałożyły się na atmosferę zagrożenia na Zachodnim Wybrzeżu, gdzie niemal panicznie obawiano się ataku ze strony Cesarstwa Japonii. Po japońskim ataku na Pearl Harbor w sumie ponad 130 tysięcy osób pochodzenia japońskiego zostało wysiedlonych z Zachodniego Wybrzeża USA i Kanady i internowanych w obozach relokacyjnych.

Wydarzenia te pozostają w Polsce tematem słabo znanym i rzadko podejmowanym przez polskich badaczy ${ }^{1}$. Warto wspomnieć, że na łamach „Białostockich Tek Historycznych" ukazały się artykuły Haliny Parafianowicz ${ }^{2}$ i Natalii Filinowicz ${ }^{3}$ poświęcone losom Japończyków w USA w czasie drugiej wojny światowej. Jeszcze trudniej o informacje na temat wysiedlenia społeczności japońskiej w Kanadzie ${ }^{4}$. Pragnę więc uzupełnić tę lukę niniejszym referatem. Szczegól-

1 Istnieje oczywiście bogata literatura w językach angielskim i japońskim. Ograniczenia objętościowe artykułu nie pozwalają mi na szczegółowe jej omówienie. Najważniejsze pozycje cytuję w przypisach.

2 H. Parafianowicz, Internowanie Japończyków w USA w czasie II wojny światowej. Próba nowego spojrzenia, „Białostockie Teki Historyczne” 2008, nr 8, s. 177-195; zob. także: eadem, Gorzka pamięć $i$ wstydliwy temat: internowanie amerykańskich Japończyków $w$ USA w czasie II wojny światowej, [w:] Pamięć historyczna kobiet, red. M. Przeniosło, K. Sierakowska, Kielce 2009, s. $133-152$.

3 N. Filinowicz, Życie amerykańskich Japończyków w obozach internowania, „Białostockie Teki Historyczne" 2013, 11, s. 211-230.

4 Tematyce tej poświęciłam artykuł Bolesna Pamięć: Wysiedlenie i internowanie społeczności japońskiej w Kanadzie w czasie II wojny światowej, „Sensus Historiae”, vol. XIV (2014/1), s. 27-49 (w którym koncentruję się na życiu wysiedlonych w kanadyjskich obozach internowania), a także pracę magisterską Losy Japończyków w Kanadzie w czasie II wojny światowej, którą napisałam pod opieką naukową prof. dr hab. Anny Reczyńskiej. Praca ta zdobyła I Nagrodę im. Nancy Burke w konkursie Polskiego Towarzystwa Badań Kanadyjskich w 2008 r. 
nie cenne dla jego powstania okazały się materiały archiwalne znajdujące się w Nikkei National Museum \& Heritage Centre w Vancouver, Nikkei Internment Memorial Centre w New Denver oraz Kamloops Japanese Canadian Museum \& Archives w Kamloops w Kanadzie. Ważnym źródłem były dokumenty rządu kanadyjskiego i inne regulacje dotyczące społeczności japońskiej w Kanadzie, opublikowane przez National Association of Japanese Canadians oraz w pracach Kena Adachiego ${ }^{5}$ i Rogera Danielsa ${ }^{6}$, a także pamiętniki, dzienniki, listy i wywiady z osobami pamiętającymi czasy drugiej wojny światowej.

Poniższy tekst ma na celu ukazanie reakcji rządu i społeczeństwa kanadyjskiego wobec mniejszości japońskiej w obliczu wojny z Japonią, których zwieńczeniem było rozporządzenie o ewakuacji Japończyków z Zachodniego Wybrzeża Kanady, wydane 24 lutego 1942 r., oraz jego realizacja. Staram się także zwrócić uwagę na wydarzenia, które poprzedziły i przyczyniły się do decyzji rządu kanadyjskiego o wysiedleniu osób pochodzenia japońskiego. Ponieważ wydarzenia w Stanach Zjednoczonych biegły podobnym jak w Kanadzie torem, zdecydowałam się na porównanie sytuacji osób pochodzenia japońskiego w tych krajach po ataku na Pearl Harbor. Próbuję odpowiedzieć na pytania o podobieństwa i różnice w podejmowaniu decyzji o wysiedleniu grupy japońskiej w Kanadzie i USA, poruszając także kwestię ewentualnej współpracy obu krajów odnośnie wspomnianej decyzji. Omawiam także politykę rządu kanadyjskiego wobec osób pochodzenia japońskiego po zakończeniu wojny.

\section{Początki społeczności japońskiej w Kanadzie}

Charakterystyczną cechą społeczności japońskiej jest jej silne zróżnicowanie generacyjne. Pierwsze pokolenie japońskich imigrantów nosi nazwę Issei, drugie określane jest mianem Nisei, trzecie - Sansei, a czwarte - Yonsei, itd. Historię napływu Japończyków do Kanady przed drugą wojną światową podzielić można na trzy specyficzne etapy: pierwszy - fazę pionierską (1877-1895), drugi - okres masowej, zorganizowanej imigracji, wyraźnie zdominowany przez przybyszów płci męskiej (1896-1907), i trzeci - okres imigracji mieszanej, z narastającą przewagą kobiet, który zapoczątkował proces zakładania rodzin w Kanadzie (od 1908 r.).

Szacunki wskazują, że w latach 1877-1895, a więc w okresie imigracji pionierskiej, do Kanady przybyło około tysiąca Japończyków? . Byli to ludzie

5 K. Adachi, The Enemy That Never Was: A History of the Japanese Canadians, Toronto: McClelland and Stewart, 1976.

6 R. Daniels, Concentration Camps: North America. Japanese in the United States and Canada During World War II, Malabar: Krieger Publishing Company, 1993.

7 W. P. Ward, The Japanese in Canada, Ottawa 1982, s. 4. 
odważni, ambitni, zdeterminowani. Ich osiedlenie się w Kanadzie zapoczątkowało zjawisko ,imigracji łańcuchowej”. Rok 1896 uznać można za koniec etapu pionierskiego a początek masowej imigracji japońskiej do Kanady. Dwie szczytowe fale przypadły na lata 1899-1900 oraz 1906-1907, kiedy to odnotowano po 11 tysięcy przybyszów z Japonii ${ }^{8}$. Lata te zbiegły się z okresem rozkwitu gospodarczego Kolumbii Brytyjskiej i nasilającego się zapotrzebowania na siłę roboczą w tej prowincji. Nie dziwi więc fakt, że Japończycy imigrujący do Kanady osiedlali się głównie na terenie Kolumbii Brytyjskiej, która - podobnie jak Kalifornia w USA - skupiała większość osób pochodzenia japońskiego. W roku 1901 aż 97\% spośród 4748 Japończyków w Kanadzie mieszkało w Kolumbii Brytyjskiej.

Większość japońskich imigrantów znajdowała zatrudnienie w sektorze rybołówstwa. Przykładowo, u ujścia rzeki Fraser, gdzie koncentrował się ówczesny połów łososi, w 1899 r. pracowało 1955 japońskich rybaków. Była to jednakże praca o charakterze sezonowym, dająca zatrudnienie jedynie w okresie od kwietnia do października. Stąd też poza sezonem japońscy imigranci zmuszeni byli poszukiwać pracy w innych sektorach gospodarczych. Charakterystyczną cechą, zwłaszcza dla wczesnego okresu osadnictwa, była bardzo duża mobilność Japończyków na rynku pracy, zarówno zawodowa, jak i geograficzna. Spora ich grupa pracowała w górnictwie, zwłaszcza w kopalniach węgla. Część znalazła zatrudnienie w przemyśle drzewnym i papierniczym, a także jako pracownicy fizyczni przy budowie kolei, wyrębie lasów, jako kucharze, żeglarze czy służba domowa $^{10}$.

Rok 1908 rozpoczął trzeci etap w historii społeczności japońskiej w Kanadzie: wiążący się z masowym napływem kobiet i procesem zakładania rodzin. Dużą rolę odegrał w tym procesie tzw. system shasshin kekkon, a więc rozpowszechniony wówczas proceder sprowadzania z Japonii do Kanady „narzeczonych z obrazka" (picture brides). Polegał on na aranżowaniu małżeństw poprzez wymianę listów i fotografii, najczęściej przy pomocy rodzin. Jeżeli kandydatka na żonę spodobała się japońskiemu imigrantowi, zapraszał ją do siebie i na miejscu dopełniano wszelkich formalności.

Większość kanadyjskich Nisei stanowiły osoby urodzone po 1910 r., zwłaszcza w latach dwudziestolecia międzywojennego. Była to grupa młoda w stosunku do drugiego pokolenia Japończyków w USA, co wynikało z faktu późniejszego przybycia pierwszych fal japońskiej imigracji do Kanady. W re-

8 Ibidem, s. 3-5.

9 Spośród pozostałych 141 osób o korzeniach japońskich, mieszkających poza Kolumbią Brytyjską, 84 osoby osiedliły się na Terytorium Yukon, 29 Japończyków zamieszkiwało Ontario, 18 - prowincje preryjne, 9 - Quebec, a 1 osoba w Nowej Szkocji, K. Adachi, op. cit., s. 33.

10 Ibidem, s. 26-27. 
zultacie proces zakładania rodzin również rozpoczął się stosunkowo później w Kanadzie niż na terytorium USA ${ }^{11}$. W 1931 r. w Kanadzie odnotowano 10728 Nisei, podczas gdy liczba Issei wynosiła 11477 osób ${ }^{12}$.

Niemal od początku swej obecności w Kolumbii Brytyjskiej Japończycy stykali się z niechętnym przyjęciem. W okresie osadnictwa pionierskiego postrzegani byli jako tajemniczy przybysze $\mathrm{z}$ dalekiej, dziwnej, zacofanej i przeludnionej Azji. Wiedza o Japonii, znajomość japońskiej kultury i historii były w społeczeństwie kanadyjskim niewielkie. Dlatego imigrantów z Japonii, podobnie jak przybyszów z Chin i innych krajów Orientu, powszechnie uważano za osoby prymitywne i nienadające się do zasymilowania. Osoby pochodzenia azjatyckiego znajdowały się na samym dole w hierarchii społeczeństwa kanadyjskiego ${ }^{13}$. Warto przy tym wspomnieć, że już pierwsza kanadyjska ustawa imigracyjna (Immigration Act) z 1869 r. zakładała, że polityka imigracyjna ma na celu zachowanie „brytyjskiego charakteru” kraju ${ }^{14}$. Był to przejaw polityki anglokonformizmu, zakładającej wyzbycie się przez imigrantów ich własnej kultury i wymagającej asymilacji z kulturą anglosaską. Ludność pochodzącą z Wysp Brytyjskich, Niemiec i Skandynawii uznawano za rasowo wyższą od pozostałych, a przy tym za łatwiejszą do asymilacji.

Należy przy tym podkreślić, że dla Japończyków przybycie do Kanady również oznaczało zetknięcie się z niezrozumiałym sposobem życia. Japońscy imigranci przekonani byli o wyższości swojej kultury. Cechowała ich nieufność wobec społeczeństwa przyjmującego. W obliczu doświadczanej dyskryminacji zaczynali izolować się od nieprzyjaznego otoczenia, co dodatkowo wzmagało nieporozumienia i napięcia.

Wizerunek Japończyków w społeczeństwie kanadyjskim z „zamazanego” i tajemniczego przybrał na przełomie XIX i XX stulecia bardziej „wyraziste rysy". Kształtowały go zasadniczo dwa czynniki: poczynania Cesarstwa Japonii na arenie międzynarodowej oraz bezpośredni kontakt Kanadyjczyków z przedstawicielami społeczności japońskiej. Początkowy podziw świata zachodniego dla przemian dokonujących się w Japonii podczas Restauracji Meiji przerodził się w niepokój i niechęć po zwycięstwie tego kraju nad Rosją w 1905 r. Wynik wojny japońsko-rosyjskiej, która przyniosła zwycięstwo państwa azjatyckiego nad potęgą europejską zaniepokoił wielkie mocarstwa. Uświadomiono sobie, że Japonia przestała być zacofanym, chylącym się ku upadkowi państwem, lecz przekształciła się w kraj nowoczesny, silny pod względem militarnym i pragnący odgrywać

\footnotetext{
11 R. Daniels, op. cit., s. 178.

12 K. Adachi, op. cit., s. 386.

13 R. Whitaker, Canadian Immigration Policy Since Confederation, Ottawa 1991, s. 10.

14 Library and Archives Canada. Statutes of Canada. An Act Respecting Immigration and Immigrants, 1869, Ottawa: SC 32-33 Victoria, chapter 10.
} 
istotna rolę na arenie międzynarodowej. Obawy płynące z tego faktu dotarły także do Kanady. W jednym z artykułów, jaki ukazał się w 1908 r. w wydawanym w Vancouver miesięczniku „Westward Ho!”, zaniepokojony redaktor magazynu pisał: „Ambicją Japonii jest stanąć na równi z ludźmi białej rasy. Nie wykazuje najmniejszego poczucia niższości i jest zdecydowana uczynić wszystko, co tylko możliwe dla wzmocnienia i utrzymania swej potęgi"15. W jeszcze mocniejszym tonie wypowiadał się na łamach pisma „British Columbia Magazine” inny dziennikarz z Kolumbii Brytyjskiej - Frank B. Vrooman: „W dniu, kiedy japońska dominacja nad Azją i Pacyfikiem stanie się faktem, kiedy (...) miliony Chińczyków staną się narzędziem w rękach Japonii, Japonia zostanie władczynią świata, a marzenie białego człowieka przerodzi się w koszmar" ${ }^{16}$. Rosnąca potęga Japonii, a także nasilenie się w tym kraju tendencji ekspansjonistycznych i nacjonalistycznych w latach trzydziestych $\mathrm{XX}$ w. pogłębiły negatywny stosunek do Japończyków w społeczeństwie kanadyjskim. Członków społeczności japońskiej zaczęto postrzegać jako osoby fanatycznie posłuszne cesarzowi, przewrotne, podstępne, a jednocześnie nielojalne w stosunku do Dominium ${ }^{17}$.

Kolejnym czynnikiem wpływającym na negatywny obraz Japończyków w społeczeństwie kanadyjskim był bezpośredni kontakt mieszkańców Zachodniego Wybrzeża Kanady z coraz większą liczbą przybyszów pochodzenia japońskiego. Białych mieszkańców Kolumbii Brytyjskiej cechowało przekonanie o wyższości kultury brytyjskiej i dążenie do zachowania anglosaskiego charakteru prowincji ${ }^{18}$. „Problem ludności orientalnej” na Zachodnim Wybrzeżu rozpoczął się wraz z przybyciem do Kanady pierwszych imigrantów chińskich, którzy w latach pięćdziesiątych XIX w. dotarli do Kolumbii Brytyjskiej w poszukiwaniu złota $^{19}$. Japończycy osiedlający się $\mathrm{w}$ Kanadzie byli więc początkowo postrzegani przez pryzmat stereotypów nagromadzonych wokół pracowników chińskich. Uważano, że stanowią zagrożenie dla brytyjskich wartości i sposobu życia. O intensywności nastrojów antyazjatyckich na Zachodnim Wybrzeżu świadczą rozruchy rasistowskie, do jakich doszło w Vancouver w 1907 r. ${ }^{20}$

Do silnych napięć dochodziło na tle rywalizacji ekonomicznej. Przykładem tego był sektor rybołówstwa, gdzie w 1912 r., pod wpływem nacisków ze strony

15 W. P. Ward, White Canada Forever. Popular Attitudes and Public Policy Toward Orientals in British Columbia, Montreal \& Kingston: McGill-Queen's University Press, 2002, s. 99.

16 Ibidem, s. 99.

17 W. P. Ward, White Canada..., s. 98-102; K. Adachi, op. cit., s. 179.

18 K. Adachi, op. cit., s. 37.

19 H. Frances, C. Tatar, W. Mattis, T. Rees, The Colour of Democracy. Racism in Canadian Society, Toronto: Hartcourt Brace Canada, 2000, s. 72.

20 Do wydarzeń tych doszło po przybyciu do Vancouver statku z ponad tysiącem imigrantów japońskich oraz kilku setkami Sikhów. Demonstracja antyjapońska, zorganizowana przez Ligę Wykluczenia Azjatów, przerodziła się w rozruchy rasistowskie, w wyniku których wiele osób zostało rannych, zob. K. Adachi, op. cit., s. 63-85. 
białych rybaków, rząd federalny zdecydował się na ograniczenie rybakom japońskim licencji połowowych. Dalsze zaostrzenia nastąpiły w latach 1919 i 1923. Wprowadzone wówczas przepisy były jednym z wielu przejawów dyskryminacji skierowanych przeciwko członkom japońskiej społeczności w Kanadzie ${ }^{21}$. Japończyków oskarżano, że godząc się na zatrudnienie za najniższe stawki psują rynek pracy i wpływają na obniżenie poziomu życia białych robotników. Bronią często stosowaną w kanadyjskiej prasie przeciwko członkom japońskiej społeczności były oszczercze zarzuty lub mocne wyolbrzymianie niekorzystnych faktów. Japończyków określano pogardliwymi słowami „Japońcy” (Japs) lub „żółta horda"22.

Przedstawione fakty świadczą o negatywnym wizerunku Japończyków w społeczeństwie kanadyjskim. Dominowała nieufność wobec obcej kulturowo i rasowo grupy, niechęć i poczucie zagrożenia własnych interesów.

\section{Żądania ewakuacji Japończyków}

Wraz z narastaniem militaryzmu japońskiego, Kolumbię Brytyjską opanowywały wybuchy natywizmu o ostrzu antyjapońskim na nieznaną dotąd skalę. Peter Ward ${ }^{23}$ wyróżnia trzy okresy nasilenia wrogości: w latach 1937-1938, 1940 oraz 1941-1942, każdy trwający kilka miesięcy. Na japońską społeczność w Kanadzie zaczęto spoglądać przez pryzmat agresywnych poczynań militarnych kraju pochodzenia jej członków. Zarzucano im, że są ludźmi zdradzieckimi, niemoralnymi i podstępnymi, a na dodatek fanatycznymi poddanymi cesarza Japonii. Jako dowód ukazywano ich przywiązanie do japońskiej kultury. Japońska inwazja na Chiny latem 1937 r. wywołała w Kolumbii Brytyjskiej falę antyjapońskich nastrojów. Wrogi stosunek wobec japońskiej mniejszości podsycały plotki o setkach nielegalnych japońskich imigrantów, którzy prowadzą w Kanadzie działalność szpiegowską i przygotowują atak na Zachodnie Wybrzeże kraju. Rząd federalny obawiał się, że antyjapońskie wystąpienia w prowincji mogą sprowokować Cesarstwo Japonii do podjęcia wrogich wobec Kanady działań oraz pokrzyżować brytyjskie interesy w Azji. Można zauważyć więc w działaniu Ottawy tendencję dążenia do rozładowywania napięć w prowincji. Powołano między innymi specjalną radę (Board of Review), której zadaniem było zbadanie doniesień o nielegalnych japońskich imigrantach. W raporcie wydanym na początku 1939 r. rada uznała plotki te za ,wielce przesadzone"24.

21 Zob. W. P. Ward, White Canada..., s. 119-123.

22 K. Adachi, op. cit., s. 63.

23 W. P. Ward, White Canada..., s. 142.

24 Ibidem, s. 144. 
Po dwóch latach względnego spokoju (1938-1939) nowa fala wystąpień natywistycznych o ostrzu antyjapońskim przetoczyła się wiosną 1940 r. przez Kolumbię Brytyjską. Tym razem sprowokowana została niekorzystnym dla aliantów przebiegiem walk z Niemcami. Z wielką podejrzliwością, a nawet lękiem spoglądano jednocześnie na każdy ruch Cesarstwa Japonii. Kozłem ofiarnym znów stała się traktowana $\mathrm{z}$ podejrzliwością i pogardą mniejszość japońska. Żądano wprowadzenia restrykcji wobec jej członków. Rząd Mackenzie Kinga znów znalazł się w niewygodnej sytuacji. Nie chcąc irytować Japonii i ryzykować konfliktu zbrojnego z kolejnym państwem, dążył do złagodzenia antyjapońskich nastrojów w prowincji. Rządowi federalnemu coraz trudniej było jednak ignorować żądania lokalnych polityków i ogarniętego poczuciem zagrożenia społeczeństwa Kolumbii Brytyjskiej. Trzeci wybuch wrogości wobec Japończyków miał miejsce w grudniu 1941 r. Japoński atak na Pearl Harbor zapoczątkował dla japońskiej mniejszości okres, który Allan Bosworth przyrównał do „tykającej bomby zegarowej, uruchomionej 7 grudnia i zdążającej do wybuchu"25.

Kanada wypowiedziała wojnę Japonii 7 grudnia 1941 r., o kilka godzin wcześniej niż uczyniły to Stany Zjednoczone. Wydarzenia wojenne na Pacyfiku doprowadziły do wybuchu paniki w Kolumbii Brytyjskiej. Obawiano się japońskiego uderzenia na terytorium prowincji, a wywiad kanadyjski donosił o możliwości istnienia tam japońskiej siatki szpiegowskiej ${ }^{26}$. Z ogromną podejrzliwością zaczęto się przyglądać japońskiej społeczności w Kanadzie, która w momencie wybuchu wojny liczyła ponad 23 tysiące osób ${ }^{27}$. Wszyscy członkowie tej grupy zostali oficjalnie uznani za „wrogich cudzoziemców” (enemy aliens) i tym samym poddani restrykcjom oraz szczególnej obserwacji. Decyzją marynarki wojennej skonfiskowano 1200 łodzi rybackich, będących głównie własnością urodzonych w Kanadzie członków japońskiej społeczności. Zamknięto 59 japońskich szkół językowych i 3 japońskie gazety ${ }^{28}$.

Wieści o kolejnych zwycięstwach Cesarstwa Japonii na Pacyfiku siały w społeczeństwie kanadyjskim strach i poczucie zagrożenia. Do akcji wkroczyły jednocześnie siły, którym najbardziej zależało na pozbyciu się Japończyków z Zachodniego Wybrzeża. Były to przede wszystkim grupy nacisku, różnego rodzaju organizacje polityczne, społeczne, militarne i ekonomiczne, zwykle o nastawieniu rasistowskim ${ }^{29}$. Po wybuchu wojny z Japonią stworzyły silny front walki o wysiedlenie Japończyków z Zachodniego Wybrzeża. Ich poglądy podzielało

\footnotetext{
25 A. Bosworth, op. cit., s. 47.

26 P. Wróbel, A. Wróbel, Kanada, Warszawa 2000, s. 156.

27 BCSC Report, [w:] L. Kawamoto Reid, B. Carter, Karizumai, Burnaby: Nikkei National Museum, 2012, s. 3.

28 R. Daniels, op. cit., s. 182.

29 Wśród grup nacisku wzywających do ewakuacji Japończyków w Kanadzie wymienić na-
} 
wielu polityków z Kolumbii Brytyjskiej. Reprezentował ich na forum ogólnokanadyjskim Ian Mackenzie - jedyny pochodzący z tej prowincji członek gabinetu w rządzie federalnym. Stanowczo popierał on pomysł ewakuacji Japończyków z Zachodniego Wybrzeża ${ }^{30}$.

Całą japońską społeczność coraz częściej zaczęto postrzegać jako „piątą kolumnę", a więc zamaskowaną grupę szpiegów i dywersantów na usługach Cesarstwa Japonii. Zarzut ten wzmagał nieufność wobec członków społeczności japońskiej w Kanadzie, a w związku z wojennymi sukcesami Japonii i klęskami aliantów na Pacyfiku budził głęboki lęk. Plotki o „,piątej kolumnie” krążyły swobodnie także w USA. W takim duchu wypowiadało się wielu amerykańskich urzędników na szczeblu federalnym i wojskowym, jak na przykład prokurator generalny stanu Kalifornia, Earl Warren, czy sekretarz marynarki wojennej Frank Knox. Pojawia się więc istotne pytanie, czy zarzuty na temat „piątej kolumny” były uzasadnione.

W rezultacie zakończonych śledztw i po przesłuchaniach przeprowadzonych przez FBI skazano tylko jednego Japończyka ${ }^{31}$. Dla kontrastu - przypadki niemieckich szpiegów w USA były bardzo liczne. Znajdowali się oni jednak w korzystniejszej sytuacji, gdyż ich wygląd nie wzbudzał podejrzeń. Wywiad kanadyjski twierdził, iż wykrył możliwość istnienia w Kolumbii Brytyjskiej japońskiej siatki szpiegowskiej. Mimo to nie znaleziono dowodów na potwierdzenie szpiegowskiej działalności wśród Kanadyjczyków pochodzenia japońskiego ${ }^{32}$. Premier Kanady, Mackenzie King, potwierdził lojalność członków mniejszości japońskiej w Kanadzie ${ }^{33}$.

Michelle Malkin, w budzącej kontrowersje książce In Defence of Internment, stając w obronie decyzji o ewakuacji Japończyków, przywołuje odtajnione przez Departament Obrony Stanów Zjednoczonych w 1977 r. informacje programu MAGIC ${ }^{34}$. Wynikało z nich, że Japonia zabiegała o pozyskanie szpie-

leży m.in.: Provincial Council of Women, Vancouver Estate Exchange, Canadian Legion in Gibson's Landing, Kinsmen's Club of Victoria, North Baurnaby Liberal Association, BC Poultry Industries Committee, Corporation of the District of Saanich, zob. W. P. Ward, British Columbia and the Japanese Evacuation, „Canadian Historical Review”, Vol. LVII, No 3: September 1976, s. 303.

30 Idem, White Canada..., s. 152.

31 FBI sprzeciwiało się akcji ewakuacji Japończyków z Zachodniego Wybrzeża USA. Szef FBI Edgar Hoover wyraził protest przeciwko planom wysiedlenia Japończyków, argumentując, że przedsięwzięcie to było „oparte w większym stopniu na społecznej i politycznej presji niż na faktycznym stanie rzeczy", A. Bosworth, op. cit., s. 86.

32 P. Wróbel, A. Wróbel, op. cit., s. 156; K. Adachi, op. cit., s. 204.

33 Prime Minister W.L. Mackenzie King on the Question of Loyalty (Aug. 4, 1944), [w:] K. Adachi, op. cit., Appendix XII, s. 431.

34 MAGIC był to amerykański program kryptologiczny, mający na celu złamanie szyfrów japońskich. Podczas wojny na Pacyfiku program MAGIC umożliwił osiągnięcie dwóch spektakularnych sukcesów: zastawienia pułapki na japońskie okręty koło wyspy Midway (czerwiec 1942 r.) oraz 
gów wśród Amerykanów i Kanadyjczyków japońskiego pochodzenia. Malkin podkreśla, iż fakt istniejących na Zachodnim Wybrzeżu siatek szpiegowskich przez długie lata osnuty był tajemnicą, uzyskano je bowiem dzięki złamaniu japońskich szyfrów ${ }^{35}$. Dekryptaże MAGIC nie zdemaskowały wszystkich agentów japońskiego wywiadu, gdyż nie udało się rozszyfrować wszystkich depesz. W świetle dostępnych obecnie danych wiadomo, że przekonanie, iż wśród Amerykanów i Kanadyjczyków japońskiego pochodzenia „,roiło się od szpiegów” było mocno przesadne. Owszem, istniały przypadki współpracy z Cesarstwem Japonii, w większości jednak głosy o ,piątej kolumnie” były zarzutami oszczerczymi ${ }^{36}$. Członkami japońskiej społeczności w Kanadzie były w większości osoby lojalne wobec Kanady. Ponieważ jednak w praktyce trudno było rozpoznać i odróżnić tych lojalnych od nielojalnych, dlatego wszystkich określono „wrogimi cudzoziemcami” i ,piątą kolumną", i jako takich wysiedlono i zamknięto w obozach internowania.

\section{Wysiedlenie społeczności japońskiej z Zachodniego Wybrzeża}

Interesujący wydaje się fakt, że o ile w Stanach Zjednoczonych silne poparcie dla ewakuacji Japończyków wyrażali członkowie rządu federalnego i wojska, o tyle w Kanadzie za wysiedleniem opowiadały się głównie osoby cywilne przede wszystkim mieszkańcy Kolumbii Brytyjskiej, nie zaś kanadyjskie władze centralne i wojskowi ${ }^{37}$.

Okazją do wyrażenia poglądów przez przedstawicieli Kolumbii Brytyjskiej na forum federalnym była konferencja dotycząca polityki wobec osób japońskiego pochodzenia, która odbyła się w Ottawie w dniach 7 i 8 stycznia 1942 r. Doszło wówczas do spotkania członków Komitetu ds. Osób z Krajów Orientu (Standing Committee on Orientals) i delegacji polityków z Kolumbii Brytyjskiej z przedstawicielami Departamentu Spraw Zagranicznych, wojska oraz Kanadyjskiej Królewskiej Policji Konnej (RCMP). Najbardziej burzliwą dyskusję w czasie obrad wzbudziła kwestia ewentualnego usunięcia osób pochodzenia japońskiego z Zachodniego Wybrzeża. Członkom konferencji nie udało się dojść do porozumienia. Antyjapońskie wystąpienia polityków z Kolumbii Brytyjskiej nie zdołały wpły-

zestrzelenia samolotu admirała Yamamoto (kwiecień 1943 r.). Program ten okazał się też niezwykle skuteczny w prowadzeniu amerykańskiej ofensywy podwodnej przeciw japońskiej żegludze, zob. J. F. Dunnigan, A. A. Nofi, Wojna na Pacyfiku: Encyklopedia, Warszawa 1998, s. 286.

35 M. Malkin, In Defence of Internement. The Case for "Racial Profiling" in World War II and the War on Terror, Washington: Regnery Publishing, 2001, s. 37-51.

36 J. F. Dunnigan, A. A. Nofi, op. cit., s. 463.

37 Zob. M. Wacławik, Losy Japończyków w Kanadzie w czasie II wojny światowej, Instytut Amerykanistyki i Studiów Polonijnych UJ, Kraków 2008 [rkps], s. 47-51. 
nąć na zmianę stanowiska wojska, RCMP i przedstawicieli władz federalnych, które pozostawały niechętne wobec planów ewakuacji. W rezultacie wydany został raport, który zalecał zaostrzenie restrykcji wobec japońskiej społeczności na Zachodnim Wybrzeżu. Postulował też utworzenie quasi-militarnych korpusów pracy dla osób pochodzenia japońskiego, pragnących czynnie wspierać wysiłek wojenny Kanady ${ }^{38}$.

Oficjalną odpowiedzią rządu federalnego na żądania ze strony przedstawicieli Kolumbii Brytyjskiej, wzywające do rozwiązania „problemu japońskiego” w prowincji, było oświadczenie wydane 14 stycznia 1942 r., w którym premier Mackenzie King złożył obietnicę „częściowej ewakuacji cudzoziemców pochodzących z kraju wroga z chronionego obszaru na Zachodnim Wybrzeżu”. Ewakuacja miała dotyczyć mężczyzn między 18. a 45. rokiem życia i przeprowadzona miała zostać przed 1 kwietnia [1942 r.]. Oświadczenie premiera stanowiło próbę kompromisowego rozwiązania tej problematycznej kwestii w obliczu uporczywych i narastających nacisków ze strony Kolumbii Brytyjskiej. 16 stycznia 1942 r. na mocy rozporządzenia nr 365 (Order-in-Council, P.C. 365) wydanego przez Królewską Tajną Radę, minister sprawiedliwości został uprawniony do ustanowienia w Kolumbii Brytyjskiej „,chronionego obszaru” ${ }^{39}$, z którego usunięci zostaną wszyscy cudzoziemcy pochodzący z krajów wrogich aliantom. Dokument ten wymierzony był przeciwko skoncentrowanym w rejonie Zachodniego Wybrzeża Japończykom, dotknął jednak również grupy osób narodowości niemieckiej i włoskiej. Podstawę prawną do wydania rozporządzenia nr 365 stanowiła ustawa War Measures Act z 1914 r.

Obietnica częściowej ewakuacji nie była jednak tym, co usatysfakcjonowałoby społeczeństwo Kolumbii Brytyjskiej. Żądano natychmiastowego wysiedlenia z prowincji wszystkich osób o japońskich korzeniach. Dla rasistowsko nastawionych grup nacisku wojna $\mathrm{z}$ Japonią stworzyła okazję, żeby pozbyć się znienawidzonej mniejszości. Większość społeczeństwa prowincji działała jednak pod presją chwili, przerażona perspektywą ewentualnego japońskiego ataku na Zachodnie Wybrzeże kraju ${ }^{40}$. Rząd federalny opierał się ewakuacji ze względów finansowych i politycznych. Po pierwsze, wobec braku dowodów nielojalności członków japońskiej społeczności nie chciano marnować środków finansowych na przeprowadzenie zbędnej akcji. Po drugie, obawiano się, że wysiedlenie japońskich mieszkańców Kanady może doprowadzić w odwecie do aktów przemocy wobec kanadyjskich jeńców wojennych ze strony Cesarstwa Japonii ${ }^{41}$.

38 Wolontariusze mieli zostać zatrudnieni przy wykonywaniu prac „o znaczeniu narodowym”, zob. W. P. Ward, White Canada..., s. 150; R. Daniels, op. cit., s. 183; K. Adachi, op. cit., s. 203-204.

39 Dwa tygodnie później za ,chronioną strefę” uznano stumilowy pas na Zachodnim Wybrzeżu Kanady, K. Adachi, op. cit., s. 212.

40 W. P. Ward, The Japanese..., s. 13.

41 K. Adachi, op. cit., s. 210-211; W. P. Ward, White Canada..., s. 162. 
Niekorzystny dla aliantów rozwój wydarzeń na Pacyfiku, a także silne naciski ze strony Kanadyjczyków zamieszkujących Zachodnie Wybrzeże skłoniły premiera do zmiany stanowiska wobec ewakuacji społeczności japońskiej. Wydane 24 lutego 1942 r. na mocy War Measures Act rozporządzenie nr 1486 (Order-in-Council, P.C. 1486) uprawniło ministra sprawiedliwości do usunięcia wszystkich osób japońskiego pochodzenia z Zachodniego Wybrzeża Kanady. Dwa dni później Louis St. Laurent, kanadyjski minister sprawiedliwości, wydał przepisy dotyczące ewakuacji. Zarządzenie dotknęło wszystkich osób o korzeniach japońskich zamieszkujących „chronioną strefę”, a więc około 21 tysięcy. Ponad 95\% japońskich mieszkańców Kanady musiało opuścić swoje domy ${ }^{42}$.

Proces ewakuacji przebiegał sprawnie i bez większych przeszkód, w dużej mierze dzięki zdyscyplinowaniu i kooperacji ze strony Japończyków, którzy nie opierali się decyzji rządu. 4 marca 1942 r. rząd federalny utworzył trzyosobową Komisję Bezpieczeństwa dla Kolumbii Brytyjskiej (British Columbia Security Commission), której przydzielono zadanie ,zaplanowania, nadzorowania i pokierowania" akcją ewakuacji. Komisja otrzymała rozległe uprawnienia. Miała prawo „wydać rozkaz wobec każdej osoby z grupy japońskiej [Japanese race - M.P.W.], przebywającej na terenie chronionego obszaru, [i zmusić ją - M.P.W.] do pozostania w miejscu zamieszkania lub do opuszczenia miejsca zamieszkania i udania się w inne miejsce (...) w takim terminie i w taki sposób, jaki zostanie wskazany przez Komisję w wydanym przez nią zarządzeniu" "43. Obowiązkiem Komisji było zapewnienie ewakuowanym mieszkania, żywności i opieki. Postanowiono też, że wszelka własność, której ewakuowany nie będzie mógł zabrać ze sobą, a wolno mu było zabrać tylko tyle, ile zdoła unieść, zostanie zarekwirowana i przekazana w ręce Nadzorcy Mienia Cudzoziemców (Custodian of Alien Property).

16 marca 1942 r. Kanadyjska Królewska Policja Konna (RCMP), pod nadzorem Komisji Bezpieczeństwa, rozpoczęła akcję przesiedleńczą Japończyków. Osoby mieszkające poza Vancouver zaczęto gromadzić w przejściowym „centrum zbiorczym" w Hastings Park. Były to tereny położone blisko linii kolejowej, przeznaczone na wyścigi konne. Na mieszkania dla ewakuowanych Japończyków wykorzystano stajnie dla koni znajdujące się w pobliżu torów wyścigowych. W Hastings Park dokonano segregacji internowanych: oddzielono mężczyzn od kobiet i dzieci, a następnie umieszczono ich w osobnych częściach obozu. Warunki życia w obozie były ciężkie. W zamyśle kanadyjskiej Komisji Bezpieczeństwa Hastings Park miał być czasowym centrum „odosobnienia i segregacji”, a Japończycy mieli w nim pozostać do czasu ukończenia prac nad budową ,sta-

\footnotetext{
42 Rozporządzenie nie objęło 5\% Japończyków mieszkających poza „chronioną strefą” Zachodniego Wybrzeża Kanady, R. Daniels, op. cit., s. 184.

43 Ibidem.
} 
łych obozów odosobnienia". Latem 1942 r. rozpoczęła się akcja przewożenia Japończyków z Hastings Park do obozów internowania. Na początku 1943 r. ostatni mieszkańcy opuścili „centrum zbiorcze”44.

Największa grupa - około 12 tysięcy osób - skierowana została do „miast duchów", a więc opuszczonych, starych miast górniczych, lub do pośpiesznie zbudowanych na ten cel schronisk. Były one przeznaczone dla kobiet i dzieci, a także mężczyzn starszych lub chorych, uznanych przez Komisję Bezpieczeństwa za niezdolnych do pracy. Około 4 tysięcy Japończyków skierowano do prowincji preryjnych, do pracy na plantacjach buraków cukrowych w Albercie i Manitobie. Około 3 tysięcy osób udało się w głąb kraju, by na własną rękę poszukiwać tam schronienia. Były to głównie osoby zamożne, którym udało się znaleźć pracę i mieszkanie poza „strefą chronioną” Zachodniego Wybrzeża. Ponad 2 tysiące mężczyzn umieszczono w specjalnych obozach pracy (road camps) w Kolumbii Brytyjskiej i Ontario, gdzie zostali zatrudnieni przy budowie dróg i mostów. Nie można pominąć też grupy 750 mężczyzn, których internowano w obozach jeńców wojennych (POW camps) w Ontario (obozy Angler i Petawa). Ludzie ci, przez Japończyków określani ganbari-ya, skazani zostali za niepodporządkowanie się rozkazom władz kanadyjskich lub też uznani za „elementy niebezpieczne”, zagrażające narodowemu bezpieczeństwu ${ }^{45}$.

Losy społeczności japońskiej w Kanadzie i w Stanach Zjednoczonych podążyły w czasie drugiej wojny światowej podobnym torem. Zarówno w USA jak i w Kanadzie wszyscy członkowie tej mniejszości (Issei i Nisei) oficjalnie uznani zostali za „wrogich cudzoziemców” i postrzegani byli jako zagrożenie dla narodowego bezpieczeństwa. Jako takich wysiedlono ich z Zachodniego Wybrzeża Ameryki Północnej i umieszczono w obozach relokacyjnych. Przy licznych podobieństwach sytuacji Japończyków w obu krajach widoczne są też pewne różnice. Wśród nich należy poruszyć kwestię silnego poparcia dla ewakuacji wśród członków rządu federalnego i armii w Stanach Zjednoczonych, przy początkowej niechęci wobec niej w analogicznych kręgach w Kanadzie. Wspomniana różnica znalazła odbicie w sposobie uprawomocnienia i przeprowadzenia akcji wysiedlenia w obu państwach. Niezdecydowanie i wątpliwości kanadyjskich władz federalnych zdradzają początkowe plany usunięcia z Zachodniego Wybrzeża wyłącznie japońskich mężczyzn i wykorzystania ich przy budowie dróg. Dopiero pod wpływem nasilającej się presji ze strony społeczeństwa Kolumbii Brytyjskiej zapadła decyzja o wysiedleniu także kobiet i dzieci. W Stanach Zjednoczonych reakcja rządu była jasna i zdecydowana. Dekret 9066 uprawomocnił wysiedlenie z Zachodniego Wybrzeża USA całej 120-tysięcznej zbiorowości japońskiej. Tymczasem brak zdecydowania w działaniu władz kanadyjskich zaowocował traumą

44 K. Adachi, op. cit., s. 252.

45 Ibidem, s. 185-186. 
rozdzielenia rodzin japońskich. Zgodnie z pierwotnymi planami, kanadyjski rząd federalny skierował japońskich mężczyzn do pracy przy budowie dróg, podczas gdy kobiety i dzieci umieszczono z czasem w obozach internowania. Społeczności japońskiej w USA oszczędzono (poza małymi wyjątkami) dramatu rozbicia rodzin.

Roger Daniels, historyk i badacz społeczności japońskiej, zauważa, że akcja wysiedlenia Japończyków była w Kanadzie gorzej zaplanowana, przebiegła jednak sprawniej niż w USA. Przeprowadzenie ewakuacji w USA było zadaniem trudnym, ponieważ liczba osób japońskiego pochodzenia wynosiła w tym kraju aż 120 tysięcy (w stosunku do 23 tysięcy w Kanadzie) ${ }^{46}$. Ewakuacja Japończyków w Stanach Zjednoczonych przebiegała pod nadzorem armii i miała charakter dwuetapowy: najpierw do przejściowych „,entrów zbiorczych”, a następnie do obozów relokacyjnych ${ }^{47}$. Podobnie jak w Kanadzie, warunki życia w amerykańskich ,centrach zbiorczych” i obozach relokacyjnych były ciężkie. Niektórzy badacze (m.in. Ken Adachi ${ }^{48}$ ) określają amerykańskie obozy relokacyjne jako bardziej surowe ze względu na fakt otoczenia ich drutem kolczastym i rozmieszczenia wież strażniczych z uzbrojonymi żołnierzami. Do argumentów przemawiających „,na korzyść” Kanady Roger Daniels w książce Concentration Camps: North America dodaje fakt, że kanadyjskie rozporządzenia nie dotknęły Japończyków pozostających w związku małżeńskim z członkiem innej grupy etnicznej ani dzieci małżeństw mieszanych. Tymczasem w Stanach Zjednoczonych za członka podlegającej wysiedleniu społeczności japońskiej uznano osoby „zawierające co najmniej 1/8 krwi japońskiej”. Fakt ten świadczy zdaniem autora o tym, że „kanadyjska polityka była mniej rasistowska”"49.

Zwolennicy uznania sytuacji Japończyków w Kanadzie za gorszą, poza bolesnym epizodem rozdzielenia japońskich rodzin, wskazują na obowiązujący Japończyków aż do 1949 r. zakaz powrotu na Zachodnie Wybrzeże Kanady. O ile pod koniec wojny ewakuowani Japończycy w USA uzyskali prawo powrotu do swych domów, członkowie japońskiej społeczności w Kanadzie (z których większość wciąż przebywała w obozach internowania) stanęli przed bolesnym dylematem wyboru między osiedleniem się na wschód od Gór Skalistych lub deportacją do Japonii ${ }^{50}$. Różnicę tę można jednak wytłumaczyć faktem istnienia w Stanach Zjednoczonych Karty Praw, na mocy której Sąd Najwyższy USA orzekł w grudniu 1944 r. w sprawie Endo (Ex parte Endo), uznając za niezgodne z prawem

\footnotetext{
46 R. Daniels, op. cit., s. 184, 192.

47 W USA było 16 centrów zbiorczych i 10 obozów relokacyjnych, zob. H. Kitano, op. cit., s. 33;

A. Bosworth, op. cit., s. 112-115.

48 K. Adachi, op. cit., s. 251.

49 R. Daniels, op. cit., s. 185.

50 Stone Voices: Wartime Writings of Japanese Canadian Issei, red. O. Keibo, Montreal 1994, s. 14 .
} 
przetrzymywanie w obozach lojalnych obywateli amerykańskich ${ }^{51}$. Decyzja ta przywróciła wolność Amerykanom japońskiego pochodzenia. Tymczasem rząd Mackenzie Kinga, który (podobnie jak rząd Roosevelta) dążył do rozwiązania „japońskiego problemu” na Zachodnim Wybrzeżu, nie był ograniczony Kartą Praw i rozstrzygniętą w oparciu o nią decyzją w sprawie Endo, mógł więc bez przeszkód realizować „politykę rozproszenia” (policy of dispersal), zakładającą rozbicie japońskich skupisk w Kolumbii Brytyjskiej i rozrzucenie Japończyków po całym terytorium Kanady ${ }^{52}$.

Trudno osądzić jednoznacznie, gdzie sytuacja Japończyków była gorsza: w Kanadzie czy w Stanach Zjednoczonych. Rację ma Roger Daniels, pisząc, że „niemożliwym jest obiektywne porównanie blizn” ${ }^{53}$. Prawdą jest natomiast, że oba kraje wyrządziły społeczności japońskiej ogromne krzywdy.

Wśród historyków pojawiły się z czasem pytania: Czy akcja przesiedlenia była efektem współdziałania między rządami Kanady i USA? Czy wpływały one w jakiś sposób na swoje decyzje? Czy może były to dwa niezależne i odrębnie zachodzące procesy? Trudno jednak o jednoznaczną odpowiedź.

Roger Daniels przywołuje powojenny raport rządu kanadyjskiego, w którym stwierdzono, iż „decyzja o ewakuacji grupy japońskiej z wybrzeża Kolumbii Brytyjskiej została podjęta jako element połączonego wysiłku Stanów Zjednoczonych i Kanady w celu obrony Zachodniego Wybrzeża Ameryki Północnej w obliczu deklaracji wojny z Japonią". Daniels uważa jednak, że w rzeczywistości istniała niewielka - jeśli w ogóle jakakolwiek - współpraca w tej kwestii. Jego zdaniem podane do opinii publicznej decyzje rządu Stanów Zjednoczonych mogły służyć jako przykład dla władz kanadyjskich. Wszelkie podobieństwa w zachowaniu rządów i społeczeństw wynikały z ,podobieństw sytuacji i ludzi [similarities of situations and peoples - M.P.W.] po północnej i południowej stronie 49 równoleżnika" ${ }^{4}$.

Ken Adachi podkreśla z kolei, że Kanadyjczycy nie potrzebowali powoływać się na ,,amerykański precedens dla usprawiedliwienia swojego działania ani też [nie musieli - M.P.W.] twierdzić, że amerykańskie plany ewakuacji wpłynęły na ich decyzję". Kanadyjska decyzja o usunięciu cudzoziemców pochodzących

\footnotetext{
51 Mitsuye Endo urodziła się i wychowała w Stanach Zjednoczonych. Nie posiadała japońskiego obywatelstwa, nie potrafiła też posługiwać się językiem japońskim. Jej brat służył w Armii Stanów Zjednoczonych. Internowana w obozie relokacyjnym Tule Lake, wypełniła petycję o sądowy nakaz nietykalności (habeas corpus). Sąd Najwyższy jednomyślnie uznał przetrzymywanie jej w obozie za niezgodne z prawem, zob. Ex Parte Mitsuye Endo, [w:] JUSTIA. US Supreme Court, https://supreme.justia.com/cases/federal/us/323/283/case.html, dostęp: 1.12.2014; R. Daniels, op. cit., s. 193; A. Bosworth, op. cit., s. 227.

52 R. Daniels, op. cit., s. 194.

53 Ibidem.

54 Ibidem, s. 182.
} 
z Japonii zapadła w Kanadzie o dwa dni wcześniej niż w USA. Adachi zwraca uwagę, że wiele amerykańskich czasopism powoływało się na rozwój wydarzeń w Kanadzie, wskazując politykę północnego sąsiada jako przykład godny naśladowania. Adachi argumentuje, że rozporządzenie wykonawcze 9066, podpisane przez prezydenta Roosevelta 19 kwietnia 1942 r., nie mogło mieć więc wpływu na posunięcia premiera Mackenzie Kinga, gdyż podjął on decyzję o potrzebie masowej ewakuacji już przed 19 kwietnia. Dekret 9066 dostarczył jednak silnego argumentu dla antyjapońskich grup nacisku, polityków z Kolumbii Brytyjskiej i innych orędowników ewakuacji w Kanadzie ${ }^{55}$.

Peter Ward, dokonując zestawienia sytuacji Japończyków na terenie Kanady i USA, stwierdza: „Podczas gdy rasowe napięcia przepełniały Kolumbię Brytyjską po ataku na Pearl Harbor, podobny kryzys dotknął amerykańskie Wybrzeże Pacyfiku. Tam, podobnie jak w Kanadzie, mieszkańcy nadbrzeżnych rejonów posiadający japońskie korzenie zostali zmuszeni do przemieszczenia się w głąb kraju do obozów skonstruowanych w celu ich przemieszczenia. (...) Nie wydaje się, aby istniała współpraca między kanadyjskim i amerykańskim rządem w procesie podejmowania decyzji i, podczas gdy wydarzenia dwóch ewakuacji biegną w bliskiej paraleli, polityka żadnego z krajów nie wywarła istotnego wpływu na sąsiada" ${ }^{56}$.

Ward, podobnie jak Daniels i Adachi, postrzega przesiedlenia przeprowadzone w Kanadzie i USA jako dwa odrębne procesy i nie dopatruje się wpływu jednego z rządów na działanie drugiego w kwestii przesiedlenia Japończyków. Odmienne stanowisko wyraża Michy Weglyn w książce Years of Sorrow, Years of Shame. Autorka stwierdza, że decyzja rządu kanadyjskiego z 16 stycznia 1942 r., dotycząca ewakuacji japońskich mężczyzn, mogła mieć „rozstrzygający wpływ na decyzję Departamentu Wojny [Stanów Zjednoczonych - M.P.W.], aby postąpić podobnie" 57 .

Kwestia ewentualnej współpracy między rządami Kanady i USA w polityce wobec społeczności japońskiej nie została jeszcze ostatecznie wyjaśniona. Nie istnieją dowody, które stwierdzałyby, że Stany Zjednoczone czerpały z rozwiązań rządu kanadyjskiego w postępowaniu wobec osób pochodzenia japońskiego ani też takie, które stwierdzałyby, że było odwrotnie. W świetle dostępnych danych wydaje się, że obie ewakuacje były odrębnymi procesami, zachodzącymi bez konsultacji i niezależnie od kraju sąsiedniego. Nie ulega wątpliwości, że Kanada nie potrzebowała usprawiedliwiać swoich działań przez odwoływanie się do posunięć władz USA. Rząd kanadyjski operował już gotowym ustawodawstwem

55 K. Adachi, op. cit., s. 215-216.

56 W. P. Ward, White Canada..., s. 197.

57 M. Weglyn, Years of Infamy: The Untold Story of America's Concentration Camps, New York: William Morrow and Company, 1976, s. 56. 
wojennym i rozwiązaniami wobec „wrogich mniejszości” (enemy aliens) z okresu pierwszej wojny światowej (War Measures Act, 1914). Nie można jednak zapominać, że żaden z krajów nie pozostawał odcięty od świata zewnętrznego. Oba państwa z uwagą obserwowały swoje poczynania i śledziły rozwój wydarzeń na terytorium sąsiada.

\section{Kolejne wykorzenienie}

4 sierpnia 1944 r. premier William Lyon Mackenzie King przedstawił w Parlamencie Kanady główne założenia polityki wobec osób pochodzenia japońskiego po zakończeniu wojny. Podkreślił, że większość Japończyków w Kanadzie pozostała w czasie wojny lojalna w stosunku do Dominium oraz że ,żadnej osobie japońskiego pochodzenia urodzonej w Kanadzie nie postawiono zarzutu sabotażu lub nielojalności”. Rząd zamierzał jednak jak najszybciej deportować tych, którzy okazali się „nielojalni” ${ }^{58}$. Premier zadeklarował też wprowadzenie całkowitego zakazu japońskiej imigracji po wojnie. Ważnym elementem przemówienia było zarysowanie założeń polityki rozproszenia wobec osób pochodzenia japońskiego. Miała ona przyczynić się do „zmniejszenia rasowej niechęci” wobec społeczności japońskiej poprzez ,rozproszenie [jej członków - M.P.W.] po całym terytorium Kanady". Powrót na Zachodnie Wybrzeże miał pozostać dla osób pochodzenia japońskiego przez pewien (nieokreślony w przemówieniu) czas zakazany. Na koniec, jakby z chęcią usprawiedliwienia swoich słów, premier podkreślił: „,nie możemy pozwolić na rozpowszechnienie się w Kanadzie wypełnionej nienawiścią doktryny rasizmu, która stanowiła podstawę nazizmu. Naszym celem jest rozwiązanie trudnego problemu w sposób, który ochroni mieszkańców Kolumbii Brytyjskiej oraz interesy całego kraju, a jednocześnie (...) powinien być zgodny z zasadami uczciwości i sprawiedliwości”59.

12 marca 1945 r. Departament Pracy wydał dokument, w którym zawiadamiał japońską społeczność w Kanadzie o wprowadzeniu przez rząd polityki rozproszenia i apelował o współpracę w realizacji jej założeń. Polityka rozproszenia była oficjalnie realizowana jeszcze przez ponad trzy i pół roku po zakończeniu wojny na Pacyfiku. Aż do 1 kwietnia 1949 r. wszystkie osoby o japońskich korzeniach w Kanadzie obowiązywał zakaz powrotu na Zachodnie Wybrzeże.

\footnotetext{
58 Wiele kontrowersji wzbudziła próba zdefiniowania słowa „nielojalni”. W 1944 r. rząd zdecydował, że oddzielenie „lojalnych” od „,nielojalnych” nastąpi w wyniku ankiet, w których każdy członek społeczności japońskiej dobrowolnie zdecyduje, czy chce pozostać w Kanadzie, zob. A. Sunahara, Politics of Racism: The Uprooting of Japanese Canadians During the Second World War, Toronto 1981, s. 102.

59 Prime Minister W.L. Mackenzie King on the Question of Loyalty (Aug. 4, 1944), [w:] Adachi, op. cit., Appendix XII, s. 431.
} 
Dla większości z nich oznaczało to więc zakaz powrotu do domu. W rezultacie konsekwentnej realizacji przez rząd polityki rozproszenia w Kanadzie wystąpiła dekoncentracja ludności japońskiej w znacznie większym stopniu niż miało to miejsce w USA, gdzie Sąd Najwyższy podważył działalność rządu federalnego ${ }^{60}$.

Paralelnie do polityki rozproszenia, rząd kanadyjski realizował program „,deportacji, repatriacji i wydalenia” Japończyków uznanych za „nielojalnych”. Każdego internowanego powyżej szesnastego roku życia, przebywającego w obozie, postawiono przed wyborem pozostania w Kanadzie i osiedlenia się na wschód od Gór Skalistych lub też ubiegania się o repatriację ${ }^{61}$ do Japonii. Za osoby do szesnastego roku życia zdecydować mieli rodzice. Rozgoryczeni, napełnieni poczuciem doznanej krzywdy, wysiedleni Japończycy aż w 49\% opowiedzieli się za repatriacją. Blisko 7 tysięcy z tej liczby stanowili dorośli, a około 3,8 tysięcy - dzieci. Co ciekawe, $3 / 5$ z blisko 11 tysięcy czekających na deportację członków społeczności japońskiej byli to urodzeni w Kanadzie Nisei, z których większość nigdy nie była w Japonii.

Do kwietnia 1946 r. aż 4527 z 6844 dorosłych Japończyków czekających na repatriację zmieniło zdanie i starało się o możliwość pozostania w Kanadzie ${ }^{62}$. Zostali oni jednak zakwalifikowani przez rząd jako osoby „nielojalne” i tym samym podlegające deportacji. Według danych, jakie prezentuje Adachi, blisko 4 tysiące członków japońskiej mniejszości zostało deportowanych do Japonii (niektórzy wbrew swej woli) nim premier Mackenzie King zdecydował się na zawieszenie niepopularnej polityki ${ }^{3}$. Działania te stanowiły pogwałcenie prawa międzynarodowego ${ }^{64}$.

Przybycie do Japonii stanowiło dla wielu Issei i Nisei kolejne ciężkie doświadczenie i nierzadko bolesne rozczarowanie. W zniszczonym wojną kraju repatrianci spotykali się z przejawami niechęci ze strony społeczeństwa japońskiego. Pokonana Japonia znalazła się w bardzo ciężkiej sytuacji gospodarczej. Straty były ogromne. W czasie wojny życie straciło około 2,1-2,5 miliona Japończyków, a 700 tysięcy uznano za zaginionych. 9 milionów pozostało bez dachu nad głową. Szacuje się, że ponad 160 japońskich miast uległo poważnym zniszczeniom, z czego 20 straciło ponad połowę zabudowy ${ }^{65}$. Ogromne rzesze

60 Zob. R. Daniels, op. cit., s. 191-192; H. Kitano, Japanese Americans. The Evolution of a Subculture, New Jersey: Prentice-Hall, 1969, s. 40.

61 Jak zauważa Daniels, termin „repatriacja”, konsekwentnie używany przez kanadyjskie władze, nie przystaje do sytuacji urodzonych w Kanadzie osób pochodzenia japońskiego, które, opuszczając ten kraj, opuszczały własną ojczyznę, R. Daniels, op. cit., s. 191.

62 A. Sunahara, op. cit., s. 109.

63 K. Adachi, op. cit., s. 317.

64 T. Kage, Uprooted Again. Japanese Canadians Move to Japan After World War II, Victoria: TI-JEAN Press, 2012, s. 3.

65 E. Pałasz-Rutkowska, K. Starecka, Japonia, Warszawa 2004, s. 189. 
repatriantów powiększały bezrobocie. Bardzo niskie plony ryżu w 1945 r. spowodowały katastrofalną sytuację na rynku żywnościowym. Według słów generała MacArthura nad Japonią zawisła groźba śmierci głodowej nawet 10 milionów ludzi ${ }^{66}$. W obliczu tak dramatycznych faktów nie dziwi podejrzliwy i niechętny stosunek głodujących Japończyków wobec przybyszów z Kanady. Warto przytoczyć tu słowa jednego z deportowanych do Japonii Nisei: „Japończycy pytali: 'Po co oni tu wracają?' No i trudno ich za to winić. Pokonany kraj. Nie mieli wystarczająco jedzenia do wykarmienia siebie, a my przybywaliśmy z kraju, gdzie było go pod dostatkiem. (...) Byliśmy dla nich obcymi. Kanadyjczykami”"67.

Do przerwania polityki deportacji przyczyniły się protesty zarówno członków mniejszości japońskiej w Kanadzie, jak też narastający opór wobec tej akcji ze strony białych Kanadyjczyków (duże wsparcie dla chcących pozostać w Kanadzie osób pochodzenia japońskiego okazała organizacja Canadian Civil Liberties Association oraz Kościoły chrześcijańskie) ${ }^{68} .24$ stycznia 1947 r. premier Mackenzie King ogłosił zakończenie realizacji programu repatriacji ${ }^{69}$.

Warto wspomnieć, że wojenne losy członków społeczności japońskiej w Kanadzie przez lata okryte były milczeniem. Pomijane były w oficjalnym dyskursie jako niewygodne dla rządu kanadyjskiego. Milczeli również byli internowani, którzy swoje wojenne doświadczenia traktowali jako upokarzające i wstydliwe. Dopiero na przełomie lat siedemdziesiątych i osiemdziesiątych XX w. zainteresowanie losami społeczności japońskiej w Kanadzie uległo ożywieniu. W obrębie tejże społeczności narodził się bowiem wówczas ruch (Redress Movement) domagający się od rządu federalnego oficjalnych przeprosin i zadośćuczynienia za krzywdy wyrządzone w czasie wojny mieszkańcom Kanady pochodzenia japońskiego $^{70}$.

22 września 1988 r. rząd kanadyjski oficjalnie przeprosił za internowanie członków japońskiej społeczności w czasie drugiej wojny światowej. Do najważniejszych elementów zadośćuczynienia należało wypłacenie każdemu z żyjących byłych internowanych odszkodowania w wysokości 21 tysięcy dolarów, a także przekazanie społeczności japońskiej (na ręce NAJC) sumy 12 milionów dolarów na cele edukacyjne i promocję praw człowieka ${ }^{71}$. Odszkodowania nie objęły jednak byłych internowanych, którzy deportowani zostali po wojnie przez rząd

\footnotetext{
66 Ibidem, s. 203.

67 B. Broadfoot, Years of Sorrow, Years of Shame: The Story of Japanese Canadians in WWII, Toronto: Dobleday \& Company, 1977, s. 322-333.

68 W. P. Ward, White Canada..., s. 164-165.

69 R. Daniels, op. cit., s. 191.

70 Zob. M. Wacławik, Bolesna pamięć..., s. 48.

71 Japanese Canadians. Redress, [w:] The Canadian Encyclopedia, http://www.thecanadianencyc lopedia.com/en/article/japanese-canadians/, dostęp: 1.12.2014.
} 
kanadyjski do Japonii. Tatsuo Kage, autor książki Uprooted Again, zwraca uwagę na „poważne zaniedbanie [tej grupy - M.P.W.] wygnańców”72 zarówno przez rząd kanadyjski i orędowników zadośćuczynienia dla mniejszości japońskiej, jak też przez badaczy.

\section{Zakończenie}

Chociaż od bolesnych wydarzeń okresu drugiej wojny światowej minęło już ponad siedemdziesiąt lat, ich wspomnienie wciąż budzi silne emocje wśród społeczności japońskiej w Kanadzie. Temat ten pozostaje żywy i istotny dla jej członków, którzy wciąż zabiegają o odpowiednie upamiętnienie tamtych wydarzeń (na przykład poprzez tablice pamiątkowe, czy specjalne ekspozycje muzealne). Powraca przy tym pytanie, jak mogło dojść do tak dramatycznych wydarzeń w Kanadzie, kraju szczycącym się demokracją i poszanowaniem praw człowieka.

Szukając odpowiedzi, konieczne jest przedstawienie ówczesnych wydarzeń w perspektywie trudnej sytuacji Kanady, jaką była jej wojna z Cesarstwem Japonii, a także uwzględnienie czynników, które wpłynęły na utrwalenie negatywnego wizerunku społeczności japońskiej jeszcze przed wybuchem konfliktu. Zwycięstwa japońskich sił lądowych na Pacyfiku siały postrach na Zachodnim Wybrzeżu Kanady, gdzie mieszkały przecież ponad 22 tysiące osób pochodzenia japońskiego. Ludzie ci, podobnie jak inni przybysze z Azji, już przed wojną byli grupa pogardzaną. Uchodzili za osoby prymitywne, obce, odporne na naciski asymilacyjne ze względu na odmienną rasę i dziwną, niezrozumiałą kulturę, i przez to niemile widziane na terytorium Kanady. Wybuch wojny przyczynił się do nasilenia wrogości wobec członków japońskiej społeczności. Zadawnione uprzedzenia rasowe nałożyły się na atmosferę zagrożenia na Zachodnim Wybrzeżu. Niespodziewany atak sił japońskich na Pearl Harbor zdawał się potwierdzać wcześniejsze przekonania większości mieszkańców Kolumbii Brytyjskiej o „zdradzieckiej i dwulicowej naturze” Japończyków. Dlatego też w oczach przeciętnego Kanadyjczyka członkowie społeczności japońskiej zaczęli jawić się jako zamaskowani szpiedzy i dywersanci na usługach cesarza Japonii. Ich obecność budziła rosnący niepokój i podejrzliwość, zwłaszcza wśród mieszkańców Zachodniego Wybrzeża, przerażonych perspektywą ewentualnej inwazji japońskiej. Nastroje te były dodatkowo podsycane przez rasistowskie grupy nacisku, dla których wojna stanowiła doskonały pretekst do pozbycia się od dawna zwalczanych intruzów. Presja wywierana na rząd federalny, aby ten zajął się problemem „niebezpiecznej” mniejszości japońskiej, rosła z każdym dniem. Wobec braku dowodów nielojalności mieszkańców Kanady pochodzenia japońskiego, a także

72 T. Kage, op. cit., s. 5. 
ze względu na wysokie koszty finansowe przeprowadzenia akcji wysiedlenia, władze kanadyjskie stanęły przed trudną decyzją. Inaczej niż w USA, których terytorium doznało bezpośredniego ataku ze strony sił japońskich i gdzie władze federalne, armia i policja wykazały silne poparcie dla ewakuacji, w analogicznych kręgach w Kanadzie zaznaczyła się początkowa niechęć wobec akcji wysiedlenia. Próby kompromisowego rozwiązania sytuacji przez władze kanadyjskie i wysiedlenia tylko mężczyzn z grupy japońskiej nie zdołały jednak uspokoić nastrojów antyjapońskich w Kolumbii Brytyjskiej. Ostatecznie rząd uległ presji i 24 lutego 1942 r. zdecydował się na wysiedlenie z Zachodniego Wybrzeża wszystkich członków japońskiej społeczności. W uzasadnieniu powołano się na kwestie „bezpieczeństwa narodowego”. Rozumowanie Kanadyjczyków zdają się trafnie wyrażać słowa Sądu Najwyższego USA, który orzekając w sprawie Korematsu w 1944 r. stwierdził: „Nie możemy zamknąć oczu na fakt, wynikający z doświadczenia, że w czasie wojny mieszkańcy etnicznie spokrewnieni z najeźdźcą mogą stanowić większe niebezpieczeństwo niż ci, którzy są innego pochodzenia"73. A ponieważ w praktyce trudno było odróżnić osoby lojalne od nielojalnych w stosunku do Dominium, zdecydowano się wysiedlić wszystkich Japończyków, przy okazji rozprawiając się z „,problemem japońskim”, istniejącym na Zachodnim Wybrzeżu na długo przed wybuchem wojny. Decyzja ta okazała się jednak fatalna dla obu stron. Dla społeczności japońskiej była ona doświadczeniem traumatycznym, dla rządu kanadyjskiego okazała się w jakimś sensie kompromitująca.

\section{Uprooted Twice: The Fate of Japanese Canadians during World War II}

\section{Summary}

In Poland there has been very little research on Japanese Canadians and their experience of incarceration during the Second World War. Therefore, this paper intends to fill in this gap. In particular, the article aims to examine the reaction of the Canadian government and society towards the Japanese Canadians in the face of the Pacific War. The paper also offers a review of the situation of the Japanese Canadian community in the pre-war Canada and describes the events that preceded and influenced the decision of the federal government to remove the Japanese Canadians from the West Coast. Since the wartime experiences of Japanese Americans and Japanese Canadians were similar, I decided to compare

73 H. Kitano, op. cit., s. 39. 
the fate of those two minorities after the Pearl Harbor attack. Also the Canadian policy towards the people of Japanese origin after the war is discussed here.

Key words: Japanese Canadians, internment, removal, uprooting, World War II, Canada

\section{Bibliografia}

\section{Materiały źródłowe}

Canada Order in Council P.C. 365 (Jan. 16, 1942), [w:] K. Adachi, The Enemy That Never Was: A History of the Japanese Canadians, Toronto 1976, Appendix V, s. $422-423$.

Canada Order in Council P.C. 1486 (Feb. 24, 1942), [w:] R. Daniels, Concentration Camps: North America. Japanese in the United States and Canada During World War II, Malabar 1993, Appendix 2, s. 209.

Ex Parte Mitsuye Endo (Dec. 18, 1944), [w:] JUSTIA. US Supreme Court, https://sup reme.justia.com/cases/federal/us/323/283/case.html, dostęp: 1.12.2014.

Great Canadian Speeches, red. D. Gruending, Markham, Ontario 2004.

Ito R., Stories of My People: A Japanese Canadian Journal, Hamilton 1994.

Konstytucja Kanady, Warszawa: Wydawnictwo Sejmowe 1998.

Nakano T. U., Nakano L., Within the Barbed Wire Fence: A Japanese Man's Account of his Internment in Canada, Seattle 1981.

Notice for Dispersal East of the Rockies Department of Labour Canada (March 12, 1945), [w:] K. Adachi, The Enemy That Never Was: A History of the Japanese Canadians, Toronto 1976, Appendix X, s. 428.

Prime Minister W.L. Mackenzie King on the Question of Loyalty (Aug. 4, 1944) [w:] K. Adachi, The Enemy That Never Was: A History of the Japanese Canadians, Toronto 1976, Appendix XII, s. 431.

Regulations of Minister of Justice Implementing the Evacuation (Feb 26, 1942), [w:] K. Adachi, The Enemy That Never Was: A History of the Japanese Canadians, Toronto 1976, Appendix VII, s. 425.

Stone Voices: Wartime Writings of Japanese Canadian Issei, red. O. Keibo, Montreal 1994.

Tunnell M., G. Chilcoat, The Children of Topaz: The Story of a Japanese-American Internment Camp, New York 1996.

Uchida Y., Desert Exile: The Uprooting of a Japanese-American Family, Seattle 1982.

U.S. Executive Order 9066 (Feb. 19, 1942), [w:] US Government Info, http://usgovinfo. about.com/od/rightsandfreedoms/a/eo9066.htm, dostęp: 1.05.2008.

War Measures Act. 1914. K. Adachi, The Enemy That Never Was: A History of the Japanese Canadians, Toronto 1976, Appendix III, s. 419-420. 


\section{Opracowania}

Adachi K., The Enemy That Never Was: A History of the Japanese Canadians, Toronto 1976.

Bangarth S., The Long, Wet Summer of 1942: The Ontario Farm Service Force, Small-town Ontario and the Nisei, „Canadian Ethnic Studies Journal”, Vol. 37, March 2005.

Benedict R., Chryzantema i miecz. Wzory kultury japońskiej, Warszawa 2003.

Bosworth A., America's Concentration Camps, New York 1967.

Broadfoot B., Years of Sorrow, Years of Shame: The Story of Japanese Canadians in WWII, Toronto 1977.

Daniels R., Concentration Camps: North America. Japanese in the United States and Canada During World War II, Malabar 1993.

Dunnigan J. F., Nofi A. A., Wojna na Pacyfiku. Encyklopedia, Warszawa 1998.

Filinowicz N., Życie amerykańskich Japończyków w obozach internowania, „Białostockie Teki Historyczne" 2013, nr 11.

Grabowski J., Historia Kanady, Warszawa 2001.

Henry F., Tatar C., Mattis W., Rees T., The Colour of Democracy. Racism in Canadian Society, Toronto 2000.

Kage T., Uprooted Again. Japanese Canadians Move to Japan After World War II, Victoria 2012.

Kawamoto Reid L., Carter B., Karizumai, Burnaby 2012.

Kitano H., Japanese Americans. The Evolution of a Subculture, New Jersey 1969.

Loewen R., Ethnic Farm Culture in Western Canada, Ottawa 2002.

Malkin M., In Defence of Internment: The Case for "Racial Profiling" in World War II and the War on Terror, Washington, DC 2004.

McAllister K. E., Captivating Debris: Unearthing a World War Two Internment Camp, „Cultural Values”, vol. V, nr 1, January 1993.

McAllister K. E., Terrain of Memory: A Japanese Canadian Memorial Project, Washington 2010.

McAllister K. E., Locating Memory: Photographic Acts, Oxford and New York 2006.

Neary P., Zennosuke Inouye's Land: A Canadian Veterans Affairs Dilemma, „The Canadian Historical Review", vol. 85, No 3, September 2004.

Pajewski J., Historia powszechna 1871-1918, Warszawa 2002.

Pałasz-Rutkowska E., Starecka K., Japonia, Warszawa 2004.

Parafianowicz H., Gorzka pamięć i wstydliwy temat: internowanie amerykańskich Japończyków w USA w czasie II wojny światowej, [w:] Pamięć historyczna kobiet, red. M. Przeniosło, K. Sierakowska, Kielce 2009.

Parafianowicz H., Internowanie Japończyków w USA w czasie II wojny światowej. Próba nowego spojrzenia, „Białostockie Teki Historyczne” 2008, nr 8. 
Roberts-Moore J., Establishing Recognition of Past Injustices: Uses of Archival Records in Documenting the Experience of Japanese Canadians During the Second World War, „Archivaria” 2002, nr 53.

Rokicki J., Kolor, pochodzenie, kultura, Kraków 2002.

Sunahara A., Politics of Racism: The Uprooting of Japanese Canadians During the Second World War, Toronto 1981.

Thompson J. H., Ethnic Minorities During Two World Wars, Ottawa 1991.

Tindall G. B., Shi D., Historia Stanów Zjednoczonych, Poznań 2002.

Tubielewicz J., Historia Japonii, Wrocław 1984.

Wacławik M. P., Bolesna Pamięć: Wysiedlenie i internowanie społeczności japońskiej w Kanadzie w czasie II wojny światowej, ,Sensus Historiae”, vol. XIV (2014/1).

Ward W. P., British Columbia and the Japanese Evacuation, „Canadian Historical Review", vol. LVII, No 3, September 1976.

Ward W. P., The Japanese in Canada, Ottawa: Canadian Historical Association, 1982.

Ward W. P., White Canada Forever: Popular Attitudes and Public Policy Toward Orientals in British Columbia, Montreal \& Kingston: McGill-Queen's University Press, 2002.

Weglyn M., Years of Infamy: The Untold Story of America's Concentration Camps, New York 1976.

Whitaker R., Canadian Immigration Policy Since Confederation, Ottawa 1991.

Wróbel P., Wróbel A., Kanada, Warszawa 2000.

Zischka A., Japonia, Warszawa, [bdw].

\section{Internet}

A More Perfect Union. Japanese Americans \& the Constitution, http://americanhistory.si. edu/perfectunion/resources/history.html, dostęp: 1.08.2015.

Japanese Canadians, w: The Canadian Encyclopedia, http://www.thecanadianencyclope dia.com/index.cfm?PgNm=TCE\&Params=A1SEC909178, dostęp: 1.08.2015.

Japanese American National Museum, http://www.janm.org/projects/inrp/english/time_ canada.htm, dostęp: 1.04.2015.

National Association of Japanese Canadians, http://www.najc.ca, dostęp: 1.08.2015.

Relocation to Redress: The Internment of the Japanese Canadians, http://archives.cbc.ca/ war_conflict/second_world_war/topics/568/, dostęp: 1.08.2015. 